\title{
Habitat preference of Great-spotted Woodpecker (Dendrocopos major Linnaeus, 1758) and Lesser-spotted Woodpecker (Dendrocopos minor Linnaeus, 1758) in the presence of invasive plant species - preliminary study
}

\author{
GÁBOR ÓNODI ${ }^{1 *} \&$ TiBOR CsÖRGÖ ${ }^{2}$
}

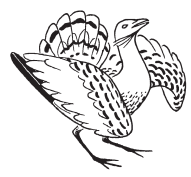

Gábor Ónodi \& Tibor Csörgő 2014. Habitat preference of Great-spotted Woodpecker (Dendrocopos major Linnaeus, 1758) and Lesser-spotted Woodpecker (Dendrocopos minor Linnaeus, 1758) in the presence of invasive plant species - preliminary study. - Ornis Hungarica 22(2): 50-64.

Abstract This study was carried out in Hungary, in an old, unmanaged, riparian poplar-willow forest, where two invasive tree species, the green ash and the boxelder maple are presented and reproduce more effectively therefore are more abundant than the native species in the study area. There are also invasive hybrid wild grapes to be found. These invasive plants cause widespread problems in floodplain forests in Central Europe. We studied Great-spotted and Lesser-spotted Woodpeckers. We investigated the following questions: Which tree species are preferred by the foraging birds? How are the foraging birds distributed spatially between the microhabitats? Are there any differences in terms of foraging niche utilization between the two studied species? We gathered our data through weekly standard observations throughout two whole years. Based on our findings we could determine that both species preferred the less abundant native trees rather than the invasive ash and maple trees, though Lesser-spotted Woodpeckers preferred hybrid wild grapes the most. Great-spotted Woodpeckers preferred the middle heights of the trees, they also moved mainly on trunks. Lesser-spotted Woodpeckers used the thinnest branches in the canopy. Based on our results we predict that the decrease of the native tree species may create a suboptimal habitat compared to the current situation. As the studied species are the major cavity excavators, the above mentioned changes will probably have significant effects on numerous cavity dependent species.

Keywords: woodpecker ecology, foraging preference, floodplain forest, invasive arboreal species, conservation

Összefoglalás A vizsgálatot a Közép-Tiszai Tájvédelmi Körzetben, egy 60-70 éves, kezeletlen füz-nyár ártéri erdőben végeztük. A területen két invazív fafaj fordul elő, az amerikai kőris és a zöld juhar. E két fafaj terjedése jelentős környezeti problémát jelent Közép-Európa szerte. Másodlagos lombkorona szintet alkotva leárnyékolják az öshonos fák újulatát, allelopatikumaikkal meggátolják az öshonos füz és nyár csemeték fejlődését. A területen szintén előforduló, invazív, hibrid szőlőfaj szintén problémát jelent. Két harkályfajt, a nagy és a kis fakopáncsot vizsgáltuk. A következő kérdésekre kerestük a választ: A táplálkozó-pihenő madarak mely fafajokat preferálják? Az egyedek milyen téreloszlásban vannak jelen a fákon? A fafaj preferenciák vizsgálatához felmértük az egyes fásszárú fajok gyakoriságát. Az adatokat egy teljes éven át, heti rendszerességgel gyüjtöttük. Az amerikai kőrist és a zöld juhart egyik vizsgált faj sem preferálta. A nagy fakopáncsok legjobban a füzfákat, a kis fakopáncsok a hibrid szőlőket részesítették előnyben. A nagy fakopáncsok a fákon föként a felsőbb régiókban, a törzsön, a kis fakopáncsok a lombsátor legvékonyabb ágain mozogtak. A jelenlegi állapothoz képest az öshonos fafajok állománycsökkenése a két harkály faj számára szuboptimális élőhely kialakulásához vezet. Mivel ezen élőhely típusban a vizsgált fajok a fő odúkészítők, az említett változások más odúlakó állatfajok helyzetét is befolyásolhatják.

Kulcsszavak: harkály ökológia, táplálék preferencia, ártéri erdő, invazív fásszárú fajok, természetvédelem

${ }^{1}$ Institute of Wildlife Management and Vertebrate Zoology, University of West Hungary, 9400 Sopron, Ady Endre utca 5., Hungary,e-mail: onodi.gabor@emk.nyme.hu

${ }^{2}$ Department of Anatomy, Cell- and Developmental Biology, Eötvös Loránd University, 1117 Budapest, Pázmány Péter sétány 1/c, Hungary

*corresponding author 


\section{Introduction}

There are 216 species in the family of woodpeckers (Picidae). Nine of 10 European species are native in Hungary (del Hoyo 2002, Gorman 2004). These species live in woody habitats and feed mainly on arthropods. Cavity-excavator species can breed only in such habitats, where trees are old and thick enough to make a cavity in (von Boltzheim \& Bauer 1980, Cramp 1985).

The picids play a key role in forest ecosystems (keystone species) (Johnsson 1993, Gorman 2011). Cavity-excavator species provide nesting cavities for other cavitydweller species. Numerous species depend on tree cavities all around the world. Cavitydweller invertebrates include numerous species of wasps (Hymenoptera), and butterflies (Lepidoptera) etc. Among vertebrates, we find secondary cavity-nester birds, such as tits (Parus spp.), flycatchers (Ficedula spp.), owls (Strigidae), the Goldeneye (Bucephala clangula), the Stock Dove (Columba oenas) etc. There are mammalian cavity-dweller species as well, for example wood mice (Apodemus spp.), dormice (Gliridae), squirrels (Sciuridae) and bats (Chiroptera) (del Hoyo 2002, Bai 2005). For the protection of cavity-dweller species, it is crucial to protect their cavity-excavators as well. Woodpecker species are considered umbrella species, as with their protection one could protect other species as well (Cramp 1985, Carlson et al. 1998, Martin \& Eadie 1999, Martin et al. 2004, Kosiński \& Ksit 2006, Kosiński et al. 2006, Smith 2006, Kosiński \& Kempa 2007, Roberge et al. 2008a,b, Edman et al. 2011, Gorman 2011, Shurulinkov et al. 2012).

For the protection of cavity-excavator species, it is crucial to protect their habitats, and so, one should study the ecologi- cal needs of the specific species. This requires studies on habitat preference. Every woodpecker species has its preferences, according to their needs. For co-existing species - and different sexes - the interspecific, intraspecific and intrasexual competition is minimized by spatial segregation, so their realised niche differ from their fundamental niche (Peters \& Grubb 1983, Pettersson 1983, Török \& Csorba 1986, Székely 1987, Török 1990, Hogstad 1971, Olsson et al. 1992, Osiejuk 1998, Stenberg \& Hogstad 2004, Pierson et al. 2010).

Our study species were the Great-spotted and Lesser-spotted Woodpeckers. The Great-spotted Woodpecker (Dendrocopos major) is a generalist species, which can inhabit nearly every kind of woody habitat in Hungary, from closed, montane forests to urban parks. This species mainly feeds on arthropods on trunks and thicker branches but will also eat seeds, fruits and small vertebrates, including bird nestlings. Depending on the species composition of competing birds, this species can use various microhabitats (Hogstad 1971, Alatalo 1978, Török \& Csorba 1986, Török 1990, Stenberg \& Hogstad 1992, del Hoyo 2002, Gorman 2004).

The Lesser-spotted Woodpecker (D. minor) breeds only in old, closed forests, with snags. This species needs snags both for foraging and nesting. The specimens mainly forage on twigs of the canopy, and prefer dead substrates for cavity excavation (Alatalo 1978, Török 1990, del Hoyo 2002, Gorman 2004, Charman et al. 2010).

As a cosequence of forestry management and agricultural practices, in Hungary the only forest types that remain in lowland landscapes in a nearly natural state are riparian forests. There are two main types of riparian forests, the one close to the river bed 
soft wood riparian gallery forests composed of poplar and willow species, while the other one further from the river bed hard wood gallery oak-ash-elm forests. Most of the latter are disappearing, as a result of river control, placing them on the other side of the dams or clearing them, for agriculture. Most of Hungary's riparian forests now consist of poplar and willow species, like white poplar (Populus alba), black poplar (P. nigra), white willow (Salix alba) and crack willow (S. fragilis). As the range of aspen ( $P$. tremula) and the range of white poplar are overlapping in Hungary, according to the high genetic similarity between aspen and white poplar, one can only find the hybrids of these two species $(P . \times$ canescens $)$ in the riparian woods. Due to the large extent of planted hybrid poplar ( $P$. × euramericana), most black poplars in these forests nowadays could be hybrids with the planted poplars as well (Gencsi \& Vancsura 2002).

There are several non-native tree species in almost every riparian forest of Hungary (and in Central Europe as well). Among them, there are two invasive species, the green ash (Fraxinus pennsylvanica) and the boxelder maple (Acer negundo). These two species reproduce faster and are much more abundant than the native species in the study area. They influence the chemical traits of the soil and also develop a second canopy layer under the native specimens' canopy and thus increasingly shade the ground preventing the saplings of the autochtonous trees from growing properly. As a result there are very few saplings of the native species in the study area (Mihály \& Botta-Dukát 2004, Erfmeier et al. 2011).

In the late $19^{\text {th }}$ and early $20^{\text {th }}$ centuries a North-American pest was introduced. This was the grape phylloxera (Daktulosphaira vitifoliae - Phylloxeridae, Hemiptera)
- which can cause lethal damage to the neck of the root of grapes. Because of that, more than two third of European vineyards died out. As a solution, some American grape species were introduced - like river bank grape (Vitis riparia) and fox grape $(V$. labrusca) - which were adapted to this insect species. People in Europe grafted their native breeds onto the rootstocks of these introduced plant species, so our grape breeds could survive (Laguna 2004, Arrigo \& Arnold 2007). These American grape species ran wild and hybridized with our native wild grape species, (V. sylvestris). This hybrid form spread quickly in the riparian woods, mainly in sparse vegetation, in clearings and forest edges. As it grows, it climbs up the trees, and can cover the whole canopy with their leaves, so the tree can die as a result of insufficient sunlight. This hybrid grape is also a widespread problem in the riparian forests in Hungary (Botta-Dukát \& Mihály 2006).

Very little is known about this relatively new habitat (though it's a widespread problem in Central Europe so far), its processes, as well as its cavity-nesting community. As the Great-spotted Woodpecker is the most generalist woodpecker species of the Western Palaearctic region, its role would be crucial for the cavity-nesting fauna of this transforming habitat. For the proper future treatments, it is important to study the habitat preferences of this well-known species (Cramp 1985, Gorman 2004, Erfmeier et al. 2011, Ónodi \& Csörgő 2012, 2013).

The questions of our study were: Which tree species are preferred by the foraging birds? How are the foraging birds distributed spatially between the microhabitats? Are there any differences in terms of foraging niche utilization between the two studied species? 
Our hypothesis suggested that the studied species do not prefer the non-native arboreal species for foraging as these species have few wood-dwelling arthropod species that could be the prey for the woodpeckers. According to the different ecological needs of the two woodpecker species, we predicted that the two species utilize different microhabitats.

\section{Material and methods}

Our study area was a 60-70-year old unmanaged riparian poplar-willow forest

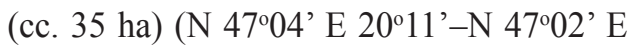
$20^{\circ} 11^{\prime}$ ) situated in the Central-Tisza Landscape Protection Area, which belongs to the Hortobágy National Park, in the floodplain area of the river Tisza. The following native tree species were recorded: white poplar, black poplar, white willow, crack willow. Among the overstorey species, there are some introduced arboreal species in the area: green ash, boxelder maple, white mulberry (Morus alba), common hackberry (Celtis occidentalis) and a hybrid wild grape (Vitis $\times$ spp.). Among them, the green ash, the boxelder maple and the hybrid wild grape known to be invasive plants as well. The midstorey consisted mainly of the saplings of the above mentioned invasive species. The other scrub layer species are European dewberry (Rubus caesius), and at the edges, the North-American bastard indigobush (Amorpha fruticosa).

Four of the nine Hungarian woodpecker species breed in the area: Great-spotted, Lesser-spotted, Green and Black Woodpecker (Picus viridis and Dryocopus martius). Our study species were the Great-spotted and Lesser-spotted Woodpecker. Previously we counted the used nesting cavities for each woodpecker species as we followed the begging calls of the nestlings. According to that examination, the two studied species had eleven and two breeding pairs respectively, and both of the Green and Black Woodpeckers had one breeding pair in the study period.

We gathered our data in the whole year of 2012 and from the autumn of 2013 until the autumn of 2014, through a weekly standard $2.5 \mathrm{~km}$ long transect line. We registered the following variables on each position where the specimens occurred in a 5 minute observation period (according to the protocols in similar studies (Hogstad 1971, Pettersson 1983, Török \& Csorba 1986, Török 1990, Osiejuk 1998): arboreal species used, tree condition, tree height, foraging height, relative distance from trunk, branch thickness, foraging technique and substrate condition.

We recorded the arboreal species of the study area in the following categories: willow species (W.), black poplar and its hybrids $(\mathrm{Pb}$.$) , white poplar and its hybrids$ (Pw.), green ash (A.), boxelder maple (M.), white mulberry $(\mathrm{Mb}$.$) , common hackberry$ (H.) and hybrid wild grape (G.).

All willow species were listed in one single category due to the very similar architecture and bark structure of the above mentioned species making it difficult to identify exact species when the branches are covered with snow. White poplar often hybridize with aspen, black poplar hybridize with hybrid American planted poplar. The white poplar and its hybrids have smoother bark and consequently have fewer prey species than the black poplar hybrids have in their more rough bark (Gencsi \& Vancsura 2002).

We recorded the frequency of each arboreal plant types among plants thicker than 3 $\mathrm{cm}$ diameter at breast height (minimum diameter of trees that support prey species of 
our study species) in 0.05 ha plots $(12.62 \mathrm{~m}$ radius) situated on a $100 \mathrm{~m}$ by $100 \mathrm{~m}$ grid.

To estimate the condition of the trees which were utilized by the foraging specimens, we assigned them to one of three categories: living trees (less than half of their branches are decayed), decaying trees (more than half of their branches are decayed, but still have living branches), snags (all of the branches are dead or branchless). During the observations, we measured the height of trees with a Christen height meter, and assigned each to one of six categories: $<5.1 \mathrm{~m}, 5.1-10 \mathrm{~m}, 10.1-15 \mathrm{~m}, 15.1-$ $20 \mathrm{~m}, 20.1-25 \mathrm{~m}, 25 \mathrm{~m}<$. We made five equal height sections to record the foraging height, and five equal sections according to the length of the branch, to register the relative distance of the given bird from trunk. In this foraging dimension, we also registered if the specimen occurred on the trunk. The thickness of the utilized branch was assigned to one of six categories: $<10.1 \mathrm{~cm}$, $10.1-20 \mathrm{~cm}, 20.1-30 \mathrm{~cm}, 30.1-40 \mathrm{~cm}, 40.1-$ $50 \mathrm{~cm}, 50 \mathrm{~cm}<$. We estimated the thickness of the branch relative to the biometric measures of the study species (length 21$23 \mathrm{~cm}$, wingspan 34-39 cm, Cramp 1985). We made three categories for foraging techniques. 'Searching' refers to those instances, when the specimen was clinging to a certain position on a tree and examined the bark surface. 'Probing' refers to a specimen that searches for prey by pecking the surface without deep blows. 'Excavating' refers to the activity when specimens peck deep into the wood. As the vegetation is very dense in the vegetation period, due to the dense lower canopy layers of the invasive trees and the upper canopy layers of the native trees, we have not studied other behaviours. It is hard to see if the birds search for their prey among the leaves or if they hunt for it above the canopies in the open air, like flycatchers (Muscicapidae). To study foraging techniques in this habitat type is therefore better suited for representing foraging techniques that occurred on the trunks or the branches, or that occurred with any sounds. We gathered data on the condition of the used substrate in two categories: "Living" and "Dead". To avoid multiple encounters with the specimens in one day, we only registered data of same sexes that occurred at least $200 \mathrm{~m}$ apart from each other (Hogstad 1971, Pettersson 1983, Török \& Csorba 1986, Morrison \& With 1987, Török 1990, Aulén \& Lundberg 1991, Suhonen \& Kuitonen 1991, Engstrom \& Sanders 1997, Osiejuk 1998, Imbeau \& Desrochers 2002, Pechacek 2006, Hogstad 2009, Czeszczewik 2010).

We gathered 572 records on Great-spotted and 45 records on Lesser-spotted Woodpeckers. We calculated the frequency distribution of each species according to all above mentioned foraging dimensions. We made Mann-Whitney tests to reveal if these distributions differ between the two species. As the frequencies of each category of tree type, tree condition and tree height is known through the previous vegetation survey, we calculated the Jacobs' preference index values for the distributions of foraging occasions of the above mentioned foraging dimension for both species. This index represents a $-1,+1$ scale from avoidance to preference respectively (Loehle \& Rittenhouse 1982, Swamidoss et al. 2012).We made Mann-Whitney tests to reveal if these distributions differ between the two species. We calculated the values of the Levin's niche breadth formula for all of the studied variables, to see if one species more specialist than the other. To compare the values of the two species we made two-sample $t$ test, 
to determine if there are any significant differences between the two species. We carried out the analyses with PAST $2.17 \mathrm{c}$ and the tables with Microsoft Office Excel 2007 software (Hammer et al. 2001).

\section{Results}

The most utilized tree type by Great-spotted Woodpeckers was the black poplar hybrids, the second was the willow, the third was the white poplar hybrids, the fourth was the green ash, the fifth was the boxelder maple, the sixth was the white mulberry and the least utilized was the common hackberry, this species did not utilize the hybrid grapes. Lesser-spotted Woodpecker utilized mostly the willow trees, the second utilized was the black poplar hybrids, the third was the grape, the fourth was the white poplar hybrids, the fifth was the green ash, the sixth was the boxelder maple and this species did not utilize the white mulberry and the common hackberry (Table 1a). The Mann-Whitney test revealed significant differences between the study species (Table 2).

Both species utilized living trees the most and snags the least (Table 1b). The Mann-Whitney test did not reveal significant differences between the two species (Table 2).

Great-spotted Woodpeckers utilized mainly the middle and Lesser-spotted Woodpeckers utilized the fourth (from the bottom) foraging height region. The not mentioned regions were represented less by both of the studied species (Table 1c). The Mann-Whitney test did not reveal any significant differences between the two species (Table 2).

Both species utilized the medium-size and the highest trees the most, Great-spotted Woodpeckers used the highest trees more exclusively. The other categories were represented less and less (Table 1d). The Mann-Whitney test revealed significant differences between the two species (Table 2).

Great-spotted Woodpeckers mainly utilized the trunks the most and the distal categories were represented less and less. The Lesser-spotted Woodpeckers used the tip of the branches the most. Additionally, this species also utilized the trunk and the middle section of the branches with lower frequencies (Table 1e). The Mann-Whitney test revealed significant differences between the two species (Table 2).

Both species mainly utilized the branches thinner than $10 \mathrm{~cm}$. The thicker branches were represented less and less, but Lesserspotted Woodpeckers utilized the thinnest branches more exclusively (Table 1f). The Mann-Whitney test revealed significant differences between the two species (Table 2).

Both species mainly showed probing behaviour. The excavating and searching behaviour were represented less (Table lg). The Mann-Whitney test did not reveal any significant differences between the two species groups (Table 2).

Both species mainly foraged on living substrates (Table $1 \mathrm{~h}$ ). The Mann-Whitney test did not reveal any significant differences between the two species (Table 2).

The frequency order of tree types from the most to the least frequent (among trees thicker than $3 \mathrm{~cm}$ ) is the following: boxelder maple (M.), green ash (A.), white poplar hybrids (Pw.), black poplar hybrids $(\mathrm{Pb}$.$) , willow (W.), white mulberry (Mb.),$ hybrid wild grape (G.) and common hackberry (H.) (Table 3a). The order of Jacobs' preference indices of tree types from the highest to the lowest values in the case of Great-spotted Woodpeckers is the following: willow, black poplar hybrids, white mulberry, white poplar hybrids, common 
a

\begin{tabular}{|l|c|c|}
\hline Tree species & GSW (572) & LSW (45) \\
\hline W. & $28 \%$ & $36 \%$ \\
\hline Pb. & $36 \%$ & $24 \%$ \\
\hline Pw. & $14 \%$ & $11 \%$ \\
\hline Mb. & $4 \%$ & $0 \%$ \\
\hline A. & $9 \%$ & $11 \%$ \\
\hline M. & $8 \%$ & $4 \%$ \\
\hline H. & $0 \%$ & $0 \%$ \\
\hline G. & $0 \%$ & $13 \%$ \\
\hline
\end{tabular}

C

C
\begin{tabular}{|l|c|c|}
\hline Foraging height & GSW $(572)$ & LSW $(45)$ \\
\hline 5th (5) & $19 \%$ & $21 \%$ \\
\hline 4th (4) & $29 \%$ & $35 \%$ \\
\hline 3rd (3) & $36 \%$ & $23 \%$ \\
\hline 2nd (2) & $10 \%$ & $16 \%$ \\
\hline 1st (1) & $6 \%$ & $5 \%$ \\
\hline Mean & 3.45 & 5.26 \\
\hline SD & 1.09 & 1.14 \\
\hline
\end{tabular}

e
\begin{tabular}{|l|c|c|}
\hline Relative distance from trunk & GSW $(572)$ & LSW $(45)$ \\
\hline trunk (0) & $49 \%$ & $24 \%$ \\
\hline 1st (1) & $13 \%$ & $3 \%$ \\
\hline 2nd (2) & $11 \%$ & $3 \%$ \\
\hline 3rd (3) & $14 \%$ & $27 \%$ \\
\hline 4th (4) & $7 \%$ & $0 \%$ \\
\hline 5th (5) & $6 \%$ & $43 \%$ \\
\hline Mean & 1.34 & 4.05 \\
\hline SD & 1.62 & 2.04 \\
\hline
\end{tabular}

g
\begin{tabular}{|l|c|c|}
\hline Foraging technique & GSW $(572)$ & LSW $(69)$ \\
\hline Searching (1) & $17 \%$ & $26 \%$ \\
\hline Probing (2) & $45 \%$ & $39 \%$ \\
\hline Excavating (3) & $38 \%$ & $35 \%$ \\
\hline Mean & 2.22 & 1.09 \\
\hline SD & 0.71 & 0.78 \\
\hline
\end{tabular}

b
\begin{tabular}{|l|c|c|}
\hline Tree condition & GSW $(572)$ & LSW $(45)$ \\
\hline Living (1) & $72 \%$ & $78 \%$ \\
\hline Decaying (2) & $23 \%$ & $20 \%$ \\
\hline Dead (3) & $5 \%$ & $2 \%$ \\
\hline Mean & 1.33 & 1.24 \\
\hline SD & 0.57 & 0.49 \\
\hline
\end{tabular}

d
\begin{tabular}{|l|c|c|}
\hline Tree height & GSW $(572)$ & LSW $(45)$ \\
\hline$<5.01 \mathrm{~m} \mathrm{(1)}$ & $4 \%$ & $18 \%$ \\
\hline $5.01-10 \mathrm{~m} \mathrm{(2)}$ & $12 \%$ & $18 \%$ \\
\hline $10.01-15 \mathrm{~m}(3)$ & $24 \%$ & $30 \%$ \\
\hline $15.01-20 \mathrm{~m}(4)$ & $15 \%$ & $9 \%$ \\
\hline $20 \mathrm{~m}<(5)$ & $45 \%$ & $25 \%$ \\
\hline Mean & 3.84 & 3.05 \\
\hline SD & 1.27 & 1.43 \\
\hline
\end{tabular}

f
\begin{tabular}{|l|c|c|}
\hline Branch thickness & GSW $(572)$ & LSW $(45)$ \\
\hline$<10.1 \mathrm{~cm}(1)$ & $48 \%$ & $81 \%$ \\
\hline $10.1-20 \mathrm{~cm}(2)$ & $19 \%$ & $7 \%$ \\
\hline $20.1-30 \mathrm{~cm}(3)$ & $16 \%$ & $5 \%$ \\
\hline $30.1-40 \mathrm{~cm}(4)$ & $9 \%$ & $2 \%$ \\
\hline $40.1-50 \mathrm{~cm}(5)$ & $4 \%$ & $2 \%$ \\
\hline $50 \mathrm{~cm}<(6)$ & $3 \%$ & $2 \%$ \\
\hline Mean & 2.13 & 2.44 \\
\hline SD & 1.39 & 1.12 \\
\hline
\end{tabular}

h
\begin{tabular}{|l|c|c|}
\hline Substrate condition & GSW $(572)$ & LSW $(45)$ \\
\hline Living (0) & $84 \%$ & $84 \%$ \\
\hline Dead (1) & $16 \%$ & $16 \%$ \\
\hline Mean & 0.16 & 0.16 \\
\hline SD & 0.36 & 0.37 \\
\hline
\end{tabular}

Table 1. Distributions of utilizations in the studied foraging dimensions (a-h). Parentheses in upper lines includes the number of cases. Parentheses next to each categories include the score of the given category

1. táblázat Hasznosítási eloszlások a vizsgált táplálkozási dimenzióban a két vizsgált harkályfaj esetében (a-h). A kategóriák melletti zárójelben az adott kategória pontszáma található

Table 2. P values of Mann-Whitney analyses in each foraging dimension. Bold numbers represent significant differences

2. táblázat Mann-Whitney teszt $\mathrm{p}$ értékei minden táplálkozási dimenzióra. A szignifikáns eltérések félkövérrel szedettek

\begin{tabular}{|l|r|}
\hline \multicolumn{1}{|c|}{ Foraging dimensions } & \multicolumn{1}{c|}{ P values } \\
\hline Tree species & $\mathbf{0 . 0 4 3 8}$ \\
\hline Tree condition & 0.4186 \\
\hline Foraging height & 0.6089 \\
\hline Tree height & $\mathbf{2 . 3 7 4 0 E - 4}$ \\
\hline Relative distance from trunk & $\mathbf{4 . 2 7 5 0 E - 7}$ \\
\hline Branch thickness & $\mathbf{8 . 6 9 1 0 E - 5}$ \\
\hline Foraging technique & 0.1785 \\
\hline Substrate condition & 0.9777 \\
\hline
\end{tabular}




\section{Availability}

\section{a}

\begin{tabular}{|l|c|}
\hline Tree species (1022) & \\
\hline W. & $8 \%$ \\
\hline Pb. & $10 \%$ \\
\hline PW. & $12 \%$ \\
\hline Mb. & $3 \%$ \\
\hline A. & $26 \%$ \\
\hline M. & $39 \%$ \\
\hline H. & $1 \%$ \\
\hline G. & $2 \%$ \\
\hline
\end{tabular}

c

\begin{tabular}{|l|r|}
\hline Tree condition (1022) & \\
\hline Living (1) & $38 \%$ \\
\hline Decaying (2) & $54 \%$ \\
\hline Dead (3) & $8 \%$ \\
\hline Mean & 1.70 \\
\hline SD & 0.60 \\
\hline
\end{tabular}

e
\begin{tabular}{|l|c|}
\hline Tree height (1022) & \\
\hline$<5.01 \mathrm{~m} \mathrm{(1)}$ & $27 \%$ \\
\hline $5.01-10 \mathrm{~m} \mathrm{(2)}$ & $40 \%$ \\
\hline $10.01-15 \mathrm{~m} \mathrm{(3)}$ & $17 \%$ \\
\hline $15.01-20 \mathrm{~m} \mathrm{(4)}$ & $9 \%$ \\
\hline $20 \mathrm{~m}<(5)$ & $6 \%$ \\
\hline Mean & 2.28 \\
\hline SD & 1.33 \\
\hline
\end{tabular}

\section{Jacobs' preference}

b

\begin{tabular}{|l|r|r|}
\hline Tree species & GSW (572) & LSW (45) \\
\hline W. & 0.6561 & 0.7222 \\
\hline Pb. & 0.6485 & 0.4887 \\
\hline PW. & 0.0849 & -0.0398 \\
\hline Mb. & 0.1512 & -1.0000 \\
\hline H. & -0.1518 & -0.4725 \\
\hline A. & -0.4997 & -0.8620 \\
\hline M. & -0.7914 & -1.0000 \\
\hline G & -1.0000 & 0.7946 \\
\hline
\end{tabular}

d

\begin{tabular}{|l|r|r|}
\hline Tree condition & GSW (572) & LSW (45) \\
\hline Living (1) & 0.6138 & 0.7050 \\
\hline Decaying (2) & -0.5968 & -0.6030 \\
\hline Dead (3) & -0.2249 & -0.7008 \\
\hline Mean & -0.0693 & -0.1996 \\
\hline SD & 0.6201 & 0.7849 \\
\hline
\end{tabular}

f

\begin{tabular}{|l|r|r|}
\hline Tree height & GSW (572) & LSW (45) \\
\hline$<5.01 \mathrm{~m} \mathrm{(1)}$ & -0.7907 & -0.2495 \\
\hline $5.01-10 \mathrm{~m} \mathrm{(2)}$ & -0.6559 & -0.5034 \\
\hline $10.01-15 \mathrm{~m} \mathrm{(3)}$ & 0.2100 & 0.3490 \\
\hline $15.01-20 \mathrm{~m} \mathrm{(4)}$ & 0.2680 & -0.0237 \\
\hline $20 \mathrm{~m}<(5)$ & 0.8418 & 0.6568 \\
\hline Mean & -0.0254 & 0.0459 \\
\hline SD & 0.6850 & 0.4634 \\
\hline
\end{tabular}

Table 3. The availability of each tree species (a), tree condition (c) and tree height (e) categories and the Jacobs' preference values of each category by the two species $(b, d, f)$

3. táblázat A különböző fásszárú fajok (a), a különböző kondíciójú fák (c) és a különböző magasságú fák (e) gyakoriság eloszlásai, illetve ezek Jacobs-féle preferencia értékei a két vizsgált faj esetében $(b, d, f)$

hackberry, green ash, boxelder maple, hybrid wild grape. The observed specimens showed avoidance to the latter four species. Lesser-spotted Woodpeckers preferred the grapes the most, the second most pre- ferred was the willow. The rest of the arboreal types were avoided by this woodpecker species. The order of avoidance from the least to the most is the following: white poplar hybrids, common hackberry, green ash, 
white mulberry and boxelder maple (Table 3b). The Mann-Whitney test did not reveal any significant differences between the two species.

The frequency order of tree condition types from the most to the least frequent (among trees thicker than $3 \mathrm{~cm}$ ) is the following: decaying trees, living trees, dead trees (Table 3c). Both studied species preferred living trees and avoided decaying trees and snags, though Great-spotted Woodpeckers avoided snags the most and the other species avoided snags the most (Table 3d). The Mann-Whitney test did not reveal any significant differences between the two species.

In the case of tree height, the 5.01-10 $\mathrm{m}$ high trees were the most frequent ones among the trees thicker than $3 \mathrm{~cm}$, the second most frequent trees were lower than $5.01 \mathrm{~m}$. The higher trees were represented less and less (Table 3e). Both woodpecker species preferred the highest trees the most, though Lesser-spotted Woodpeckers showed slight avoidance to the second highest category. The lower tree categories were represented less and less, as the two species showed avoidance to the two lowest tree categories (Table 3f). The Mann-Whitney test did not reveal any significant differences between the two species.

Great-spotted Woodpecker showed higher niche-breadth values in terms of tree condition, relative distance from trunk, branch thickness and substrate condition. Lesserspotted Woodpecker showed higher nichebreadth values in terms of tree species, foraging height, tree height and foraging technique. Although Great-spotted Woodpecker showed higher mean niche-breadth value, the two-sampled t test did not reveal any significant differences between the two species.

\section{Discussion}

Although the studied species are among the most common woodpecker species, very few researchers studied the foraging preferences of these species and moreover no one did survey these woodpecker species in the presence of these invasive arboreal species. For proper conservation efforts, we have found it crucial that more researchers should study these new habitat types.

In the study area Great-spotted Woodpeckers foraged mainly on native trees, in the upper regions, on branches and trunks thinner than $10 \mathrm{~cm}$. The birds preferred living trees. It is a common phenomenon, that Great-spotted Woodpeckers use living branches of living trees for foraging, while other species prefer decaying or dead trees and dead substrates (Török 1990, Smith 2007, Lõhmus et al. 2010). Compared to other Dendrocopos species, the Great-spotted Woodpecker prefers living trees the most. The White-backed Woodpecker (Dendrocopos leucotos) for instance is a dead wood specialist. Although its body size and bill length is significantly greater than the study species', White-backed Woodpecker forages exclusively on softer dead wood. According to Aulén and Lundberg (1991), the Great-spotted Woodpecker's shorter but stronger bill seems to be a more efficient tool for excavating fresh/hard substrates, than the White-backed Woodpecker's longer and less robust bill.

As the Great-spotted Woodpecker is a generalist species, it can forage in various microhabitats according to the architecture of the habitat, the distribution of prey species and the spatial distribution of the competitor species etc. In a similar paper in poplar-willow forest patches, where the same four woodpecker species bred and the 
above mentioned invasive arboreal species were present only in the midstorey, we have found similar preferences, as the Great-spotted Woodpeckers preferred the poplar and willow trees, and used the same microhabitats, the upper parts of the trunk (Ónodi \& Csörgő 2012, 2013). In another work in Hungary, which took place in a middle-aged oak forest Great-spotted Woodpeckers used the upper parts of trees too, in the presence of Middle-spotted Woodpeckers (Török \& Csorba 1986). In another oak forest, where the Middle- and Lesser-spotted Woodpeckers were the competitors, the Great-spotted Woodpeckers used the lower regions of the trunk in the breeding season, as the other species moved mainly in the upper regions. More precisely, the Middle-spotted Woodpeckers used the thicker and Lesser-spotted Woodpeckers used the thinner branches (Török 1990). The smaller species like the Middle- and Lesser-spotted Woodpeckers are more agile than Great-spotted Woodpeckers, so in habitats, where the above-mentioned species were both present, Great-spotted Woodpeckers did not use the uppermost regions and the thinnest branches. In our study area, there are not any Middle-spotted Woodpeckers, so Great-spotted Woodpeckers could mainly use the thinner trunk in the upper regions. In a pine forest in Finland, the Great-spotted Woodpeckers coexisted with Lesser-spotted, Black and Grey-headed Woodpeckers. In that study, the Great-spotted Woodpecker used mainly the upper regions, more precisely the thicker branches. The Black and the Grey-headed Woodpeckers were weak competitors for Great-spotted Woodpeckers as they foraged mainly on the ground and on the lower parts of the trunk for ants. As the Lesser-spotted Woodpecker is the smallest European woodpecker species, it makes common sense, that this species is more specialist, than the Great-spotted Woodpecker as the Lesser-spotted Woodpeckers use the upper parts of trees, they forage in the canopy, on the thinnest branches (Alatalo 1978, Török 1990, Charman et al. 2010).

As the bark structure of the tree species living in the study area is so different and some of those species could have rich food supply underneath the bark, the specimens showed mostly probing behaviour, when the birds gather their food without subcambial excavations. There are subcambial prey items as well in the wood of the native trees. As native trees are less frequent than the invasive species this situation could be the cause of that the birds showed the excavating behaviour less frequently than the probing behaviour. Great-spotted Woodpeckers showed the probing behaviour most frequently in other studies as well, like in the above mentioned study of Török (1990), where this species used almost exclusively oak trees, which have rough bark structure as well, with more arthropods. As in other studies, Lesser-spotted Woodpeckers used the probing technique the most among the three studied foraging techniques as well as the other species. The frequent utilization of the probing behaviour could be due to the woodpeckers trying to optimise the costs and benefits of foraging activities as it could be the most energy saving and still effective foraging behaviour. On the other hand it could be due to that most prey species lives closer to the surface underneath the bark. Both suggestions need further studies. According to other studies, both species use the gleaning technique mainly in the breeding season, and Lesser-spotted Woodpecker uses it more exclusively. This study is not suited for the examination of neither seasonal differences (due to the low amount of 
data on Lesser-spotted Woodpecker) and nor the use of gleaning technique (due to the highly stratified architecture of the studied habitat in vegetation periods (Alatalo 1978, Török 1990, Smith 2007, Böhm et al. 2009, Charman et al. 2010).

The arboreal species preferences of the studied birds were similar in terms of native trees as they preferred the rough-barked willow trees and black poplar hybrids the most. Among the native trees, the third preferred species was the white poplar hybrids. Only the white poplar hybrids' bark is smooth among the native trees, so fewer prey species could inhabit their bark. The black poplar hybrids are the oldest and biggest trees in the study area, therefore their wood could be rotten in larger volumes, providing suitable microhabitats for numerous wood-boring insect species. These trees could have more arthropods in and underneath the bark of their trunks, in their decaying and dead limbs and even in their living branches. These characteristics can make the living, but internally decaying branches the most utilized substrate type for both of the studied species. These woodpecker species may prefer wood-dwelling arthropods which live in living or partially decayed branches in the study area. This requires future entomological studies.

White mulberry trees prefer dryer soils. They don't tolerate the 2-3 year floods well, so most mulberry trees in this habitat type are decaying with numerous partially dead or dead branches providing suitable habitat for woodpecker prey species. This could be the result of the high preference shown for them by the Great-spotted Woodpecker, despite the low abundance of this tree species (Mihály \& Botta-Dukát 2004).

In North America, the green ash and the boxelder maple occupy the midstorey and the lower canopy layer of the willow-poplar riparian forests as mid-successional species supporting diverse bird communities (Hodorff \& Hull Sieg 1986, Rumble $\&$ Gobeille 1998). These species survive more successfully in the shade and grow better at the clearings of the source-rich European riparian forests, than the European willow and poplar species (Saccone et al. 2010, Porté et al. 2011). Both non-native species have secondary metabolic products that prevent herbivory and wood boring insects inhabiting their inner tissues. These species also produce allelopathic chemicals that can prevent the saplings of native species from developing properly (Csiszár 2009, Csiszár et al. 2013). Green ash supports very few wood boring insect species. Among them, the most common one is the ash bark beetle Leperesinus fraxini (Scolytidae), which lives in the bark of the trees. Only Great-spotted Woodpeckers pecked the bark of this tree species. According to the literature, there are not any known wood boring insect species in the living wood of boxelder maple in Europe. Among the few records $(n=46)$, that were gathered at boxelder maples, the birds showed excavating behaviour near as frequent as probing or searching. That suggested that some arthropod species could have inhabited the wood of the maple trees. This problem needs further entomological surveys. Although in early spring in the study area one could find boxelder maples 'ringed' by Great-spotted Woodpeckers (they made horizontal rows of little holes, so that they can feed on the sap that percolates from the phloem), but in the study period, we've never collected any records on this kind of behaviour as the frequency of this activity is much lower comparing to the other foraging behaviours that were represented (Gencsi \& 
Vancsura 2002, Gorman 2004, Mihály \& Botta-Dukát 2004).

As the green ash and the boxelder maple are the two most avoided tree species in our study, we can confidently predict that the population decrease of the native tree species will probably lead to a suboptimal habitat compared to the current situation. Under these conditions the size of the woodpecker territories is predicted to increase, resulting in lower densities. As the most common cavity excavators, the studied woodpecker species play key role in alluvial forest communities, the above mentioned changes would have significant effects on the population dynamics of numerous cavity-dependent species. Though the Great-spotted Woodpecker could be a serious nest predator for cavity-nesting bird species, and so some species avoid nesting in woodpecker cavities (Wesolowski 2007), this species is the main excavator in the study area. Some species avoid the holes of the studied species, instead they nest in naturally decayed cavities. In many cases, the decaying processes are initiated by the excavating work of foraging woodpeckers, as they can inoculate wood-decaying fungi into wood. Woodpecker-excavated foraging holes could be nesting cavities through decaying processes a couple of decades later. As the invasive tree species have harder wood, these trees decay slower than the native willow and poplar trees, the importance of woodpecker-made foraging and nesting cavities will surely increase (Farris et al. 2004, Jackson \& Jackson 2004).
These invasive arboreal species have been present in Hungary and across Europe for more than a century and so they are widespread nowadays. These species transformed their new habitats, forming entirely new ecosystems that never existed before. The restoration of these highly transformed habitats would be very source-intensive, if even possible, the managements could mean too much harm to the habitat. South-African and Australian authors termed these transformed ecosystems as 'emerging' or 'novel' ecosystems. They considered that adaptive management strategies could be the most successful ways to secure the current processes of these ecosystems while trying to preserve the native vegetation as much as possible (Milton 2003, Hobbs et al. 2006, Lindenmayer et al. 2008, Hobbs et al. 2013).

\section{Acknowledgements}

We would like to express our gratitude to the directorate of the Hortobágy National Park, who gave permission for our field work, to Béla Tallósi, the ranger of the study area, to Dániel Winkler, the first author's supervisor at the University of West Hungary for his support and help with the analyses and to Daniel Hayhow and Zoltán Szilágyi, who improved the English of our paper and to the anonymous reviewers of Ornis Hungarica who gave helpful advices for the manuscript. Tibor Csörgő was supported by OTKA 108571. 


\section{References}

Alatalo, R. H. 1978. Resource partitioning in Finnish woodpeckers. - Ornis Fennica 55: 49-59.

Arrigo, N. \& Arnold, C. 2007. Naturalised Vitis rootstocks in Europe and consequences to native wild grapevine. - PLoS ONE 2:e521. DOI: 10.1371/ journal.pone.0000521

Aulén, G. \& Lundberg, A. 1991. Sexual dimorphism and patterns of territory use by the White-backed Woodpecker Dendrocopos leucotos. - Ornis Scandinavica 22(1): 60-64.

Botta-Dukát, Z. \& Mihály, B. 2006. (eds.) Biológiai inváziók Magyarországon. Özönnövények II. [Biological invasions in Hungary. Invasive plants II.]. - Természetbúvár Alapítvány Kiadó, Budapest, pp. 410 (in Hungarian)

Carlson, A., Sandström, U. \& Olsson, K. 1998. Availability and use of natural tree holes by cavity nesting birds in a Swedish deciduous forest. - Ardea 86: 109-119.

Charman, E. C., Smith, K. W., Gruar, D. J., Dodd, S. \& Grice, P. V. 2010. Characteristics of woods used recently and historically by Lesser-spotted Woodpeckers Dendrocopos minor in England. - Ibis 152: 543-555. DOI: 10.1111/j.1474919X.2010.01020.X

Cramp, S. 1985. The birds of the Western Palearctic. Vol. IV. - Oxford University Press, Oxford, pp. 960

Csiszár, Á. 2009. Allelopathic effects of invasive woody plant species in Hungary. - Acta Silvatica \& Lignaria Hungarica 5: 9-17.

Csiszár, Á., Korda, M., Schmidt, D., Špor, D., Süle, I. P., Teleki, B., Tiborcz, V., Zagyvai, G. \& Bartha, D. 2013. Allelopathic potential of some invasive plant species occurring in Hungary. - Allelopathy Journal 31: 309-318.

Czeszczewik, D. 2010. Wide intersexual niche overlap of the specialized White-backed Woodpecker Dendrocopos leucotos under the rich primeval stands in the Białowieża Forest, Poland. - Ornis Polonica 51: 241-251.

del Hoyo, J., Elliott, A. \& Sargatal, J. (eds.) 2002. Handbook of the birds of the World. Vol. VII. Jacamars to woodpeckers. - Lynx Edicions, Barcelona, pp. 613

Edman, T., Angelstam, P., Mikusinski, G., Roberge, J-M. \& Sikora, A. 2011. Spatial planning for biodiversity conservation: Assessment of forest landscapes' conservation value using umbrella species requirements in Poland. - Landscape and Urban Planning 102: 16-23.

Engstrom, R. T. \& Sanders, F. J. 1997. Red-cockaded Woodpecker foraging ecology in an old- growth longleaf pine forest. - The Wilson Bulletin 109(2): 203-217.

Erfmeier, A., Böhnke, M. \& Bruelheide, E. 2011. Secondary invasion of Acer negundo: the role of phenotypic responses versus local adaptation. - Biological Invasions 13: 1599-1614. DOI: 10.1007/ s10530-010-9917-2

Farris, K. L., Huss, M. J. \& Zack, S. 2004. The role of foraging woodpeckers in the decomposition of Ponderosa pine snags. - The Condor 106: 50-59.

Gencsi, L. \& Vancsura R. 2002. Dendrológia [Dendrology]. - Mezőgazda Kiadó, Budapest, pp. 728 (in Hungarian)

von Blotzheim, U. N. G. \& Bauer K. M. 1980. Handbuch der Vogel Mitteleuropas. Band 9. Columbiformes - Piciformes - Akademische Verlagsgesellschaft, Wiesbaden, pp. 279

Gorman, G. 2004. Woodpeckers of Europe. A study of the European Picidae. - Bruce Coleman, Chalfont St Peter pp. 192

Gorman, G. 2011. The Black Woodpecker. A monograph on Dryocopus martius. - Lynx Edicions, Barcelona, pp. 184

Hammer, O., Harper, D. A. T. \& Ryan, P. D. 2001. PAST: Paleontological statistics software package for education and data analysis. - Palaeontologia Electronica 4(1): 9.

Hobbs, R. J., Arico, S., Aronson, J., Baron, J. S., Bridgewater, P., Cramer, V. A., Epstein, P. R., Ewel, J. J., Klink, C. A., Lugo, A. E., Norton, D., Ojima, D., Richardson, D. M., Sanderson, E. W., Valladares, F., Vilà, M., Zamora, R. \& Zobel, M. 2006. Novel ecosystems: theoretical and management aspects of the new ecological world order. Global Ecology and Biogeography 15: 1-7. DOI: 10.1111/j.1466-822x.2006.00212.x

Hobbs, R. J., Higgs, E. S. \& Hall, C. M. (eds.) 2013. Novel ecosystems. Intervening in the new ecological world order. - Wiley-Blackwell, Chichester, pp. 368

Hogstad, O. 1971. Stratification in winter feeding of the Great-spotted Woodpecker Dendrocopos major and the Three-toed Woodpecker Picoides tridactylus. - Ornis Scandinavica 2: 143-146.

Hogstad, O. 2009. Sexual differences of labour during breeding activities and territory use in the Lesser-spotted Woodpecker Dendrocopos minor. - Ornis Norvegica 32: 42-48.

Imbeau, L. \& Desrochers, A. 2002. Foraging ecology and use of drumming trees by Three-toed Woodpeckers. - The Journal of Wildlife Management 66(1): 222-231. 
Jackson, J. A. \& Jackson, B. J. S. 2004. Ecological relationships between fungi and woodpecker cavity sites. - The Condor 106(1): 37-49.

Johnsson, K. 1993. The Black Woodpecker Dryocopus martius as a keystone species in forest. Summary of the thesis. - In: Johnsson, K. 1993. The Black Woodpecker Dryocopus martius as a keystone species in forest. Report 24. - Swedish University of Agricultural Sciences, Department of Wildlife Ecology, Uppsala, pp. 49-65.

Kosiński, Z. \& Kempa, M. 2007. Density, distribution and nest sites of woodpeckers Picidae in a managed forest of Western Poland. Polish Journal of Ecology 55: 519-533. DOI: 10.5735/086.051.0402

Kosiński, Z. \& Ksit, P. 2006. Comparative reproductive biology of Middle-spotted Woodpeckers Dendrocopos medius and Great-spotted Woodpeckers $D$. major in a riverine forest. - Bird Study 53: 237-246. DOI: 10.1080/00063650609461438

Kosiński, Z., Ksit, P. \& Winiecki, A. 2006. Nest sites of Great-spotted Woodpeckers Dendrocopos major and Middle-spotted Woodpeckers Dendrocopos medius in near-natural and managed riverine forests. - Acta Ornithologica 41: 21-32. DOI: 10.3161/068.041.0108

Laguna, E. 2004. American and hybrid grapevines ( $\mathrm{Vi}$ tis spp.): A new concept of invasive plants to Europe. $-4^{\text {th }}$ European Conference on the Conservation of the Wild Plants. - A workshop on the implementation of the Global Strategy for Plant Conservation in Europe, Valencia, Spain

Lindenmayer, D. B., Fischer, J., Felton, A., Crane, M., Michael, D., Macgregor, C., Montague-Drake, R., Manning, A. \& Hobbs, R. J. 2008. Novel ecosystems resulting from landscape transformation create dilemmas for modern conservation practice. - Conservation Letters 1: 129-135. DOI: 10.1111/j.1755-263X.2008.00021.x

Loehle, C. \& Rittenhouse, L. R. 1982. An analysis of forage preference indices. - Journal of Range Management 35(3): 316-319.

Lõhmus, A., Kinks, R. \& Soon, M. 2010. The importance of dead-wood supply for woodpeckers in Estonia. - Baltic Forestry 16(1): 76-86.

Martin, K. \& Eadie, J. M. 1999. Nest webs: A community-wide approach to the management and conservation of cavity-nesting forest birds. - Forest Ecology and Management 115: 243-257.

Martin, K., Aitken, K. E. H. \& Wiebe, K. L. 2004. Nest sites and nest webs for cavity-nesting communities in interior British Columbia, Canada: nest characteristics and niche partitioning. - The Condor 106: 5-19.
Mihály, B. \& Botta-Dukát, Z. (eds.) 2004. Biológiai inváziók Magyarországon. Özönnövények [Biological invasions in Hungary. Invasive plants]. Természetbúvár Alapítvány Kiadó, Budapest, pp. 409 (in Hungarian)

Milton, S. J. 2003. 'Emerging ecosystems': a washing-stone for ecologists, economists and sociologists? - South African Journal of Science 99: 404406.

Morrison, M. L. \& With, K. A. 1987. Interseasonal and intersexual resource partitioning in Hairy and White-headed Woodpeckers. - The Auk 104(2): 225-233.

Olsson, O., Nilsson, I. N., Nilsson, S. G., Pettersson, B., Stagen, A. \& Wiktander, U. 1992. Habitat preferences of the Lesser-spotted Woodpecker Dendrocopos minor. - Ornis Fennica 69: 119-125.

Ónodi, G. \& Csörgő, T. 2012. A nagy fakopáncs (Dendrocopos major Linnaeus, 1758) élöhely preferenciája nagy mozaikosságú élőhelyen [The habitat preference of the Great-spotted Woodpecker (Dendrocopos major Linnaeus, 1758) in a mosaic habitat]. - Természetvédelmi Közlemények 18: 402-414. (in Hungarian with English Summary)

Ónodi, G. \& Csörgö, T. 2013. Relationship between vegetation structure and abundance of Great-spotted Woodpeckers (Dendrocopos major) in a mosaic habitat. - Ornis Hungarica 21(1): 1-11. DOI: 10.2478/orhu-2013-0011

Osiejuk, T. S. 1998. Study on the intersexual differentation of foraging niche in relation to abundance of winter food in Great-spotted Woodpecker Dendrocopos major. - Acta Ornithologica 33: 135-141.

Pechacek, P. 2006. Foraging behavior of Eurasian Three-toed Woodpeckers (Picoides tridactylus alpinus) in relation to sex and season in Germany. - The Auk 123(1): 235-246. DOI: 10.1642/0004-8038(2006)123[0235:FBOETW]2. $0 . \mathrm{CO} ; 2$

Peters, W. D. \& Grubb, T. C. Jr. 1983. An experimental analysis of sex-specific foraging in the Downy Woodpecker, Picoides pubescens. - Ecology 64: 1437-1443.

Pettersson, B. 1983. Foraging behaviour of the Middle-spotted Woodpecker Dendrocopos medius in Sweden. - Holarctic Ecology 6: 263-269. DOI: 10.1111/j.1600-0587.1983.tb01090.x

Pierson, J. C., Allendorf, F. W., Saab, V., Drapeau, P. \& Schwartz, M. K. 2010. Do male and female Blackbacked Woodpeckers respond differently to gaps in habitat? - Evolutionary Applications 3: 263278. DOI: $10.1111 / j .1752-4571.2009 .00111 . x$

Porté, A. J., Lamarque, L. J., Lortie, C. J., Michalet, R. \& Delzon, S. 2011. Invasive Acer negundo out- 
performs native species in non-limiting resource environments due to its higher phenotypic plasticity. - BioMed Central Ecology 11: 28. DOI: 10.1186/1472-6785-11-28

Roberge, J-M., Angelstam, P. \& Villard, M-A. 2008a Specialised woodpeckers and naturalness in hemiboreal forests. Deriving quantitative targets for conservation planning. - Biological Conservation 141: 997-1012. DOI: 10.1016/j.biocon.2008.01.010

Roberge, J-M., Mikusinski, G. \& Svensson, S. 2008b The White-backed Woodpecker: umbrella species for forest conservation planning? - Biodiversity Conservation 17: 2479-2494. DOI: 10.1007/ s10531-008-9394-4

Rumble, M. A. \& Gobeille, J. E. 1998. Bird community relationships to succession in green ash (Fraxinus pennsylvanica) woodlands. - American Midland Naturalist 140: 372-381. DOI: 10.1674/0003-0031(1998)140[0372:BCRTSI]2.0. $\mathrm{CO} ; 2$

Saccone, P., Brun, J-J. \& Michalet, R. 2010. Challenging growth-survival trade-off: a key for Acer negundo invasion in European floodplains? - Canadian Journal of Forest Research 40: 1879-1886.

Shurulinkov, P., Stoyanov, G., Komitov, E., Daskalova, G. \& Ralev, A. 2012. Contribution to the knowledge on distribution, number and habitat preferences of rare and endangered birds in Western Rhodopes Mts, Southern Bulgaria. Strigiformes and Piciformes. - Acta Zoologica Bulgarica 64 : 43-56.

Smith, K. W. 2006. The implications of nest site competition from Starlings Sturnus vulgaris and the effect of spring temperatures on the timing and breeding performance of Great-spotted Woodpeckers Dendrocopos major in southern England. - Annales Zoologici Fennici 43(2): 177-185.
Smith, K. W. 2007. The utilization of dead wood resources by woodpeckers in Britain. - Ibis 149(Suppl. 2): 183-192.

Stenberg, I. \& Hogstad, O. 1992. Habitat use and density of breeding woodpeckers in the 1990's in More og Romsdal County, western Norway. Fauna Norvegica Ser. C, Cinclus 15: 49-61.

Stenberg, I. \& Hogstad, O. 2004. Sexual dimorphism in relation to winter foraging in the White-backed Woodpecker (Dendrocopos leucotos). - Journal of Ornithology 145: 321-326. DOI: 10.1007/ s10336-004-0045-6

Suhonen, J. \& Kuitunen, M. 1991. Intersexual foraging niche differentiation within the breeding pair in the Common Treecreeper Certhia familiaris. - Ornis Scandinavica 22(4): 313-318.

Swamidoss, P. D., Sudhakaran, M. R. \& Parvathiraj, P. 2012. Habitat preference of microchiropteran bats in three districts of Tamilnadu, South India. - International Research Journal of Biological Sciences 1(5): 24-30.

Székely, T. 1987. Foraging behaviour of woodpeckers (Dendrocopos spp.), Nuthatch (Sitta europaea) and treecreeper (Certhia sp.) in winter and spring. - Ekologia Polska 35: 101-114.

Török, J. \& Csorba, G. 1986. Táplálék szegregáció négy fatörzsön táplálkozó madárfajnál [Foraging segregation in four bark-foraging bird species]. Állattani Közlemények 73: 101-113. (in Hungarian with English Summary)

Török, J. 1990. Resource partitioning among three woodpecker species Dendrocopos spp. during the breeding season. - Holarctic Ecology 13: 257264.

Wesolowski, T. 2007. Lessons from long-term hole-nester studies in a primeval temperate forest. - Journal of Ornithology 148: 395-405. DOI: 10.1007/s10336-007-0198-1

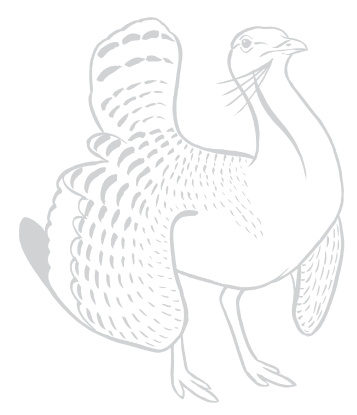

